\title{
Drying kinetics and thermodynamic properties of pigeon pea beans
}

\section{Cinética de secagem e propriedades termodinâmicas dos grãos de Feijão-Guandu}

\author{
Rayonny Batista MAIA'; Samuel Gonçalves Ferreira Dos SANTOS²; Juliano Silva QUEIROZ $^{3}$; \\ Renato Souza RODOVALHO ${ }^{4}$; Daniel Pereira SILVA ${ }^{5}$
}

${ }^{1}$ Autor para correspondência, Acadêmico do curso de Zootecnia, Instituto Federal Goiano - Campus Ceres,
raionney_maia@hotmail.com
${ }^{2}$ Acadêmico do curso de Agronomia, Instituto Federal Goiano - Campus Ceres, samuel-2100@hotmail.com
${ }^{3}$ Acadêmico do curso de Agronomia, Instituto Federal Goiano - Campus Ceres, julianoagro260@gmail.com
${ }^{4}$ Doutor em Agronomia, IF Goiano - Campus Ceres, renato.rodovalho@ifgoiano.edu.br
${ }^{5}$ Acadêmico do curso de Agronomia, Instituto Federal Goiano - Campus Ceres, danielsilva.agron@gmail.com

Recebido em: 22-11-2018; Aceito em: 19-02-2019

\begin{abstract}
Pigeon pea is a common plant cultivated in family farming. It is often used as a source of protein for animal breeding. The knowledge of the drying kinetics and the thermodynamic properties of pigeon pea beans (Cajanus cajan) is relevant for simulation of drying, which aims to maintain the quality of beans. The objective of this study is to estimate the drying curves of pigeon pea beans using mathematical models. This study also aims to determine their thermodynamic properties. Forced-drying greenhouses were used for the drying process. The initial water content of pigeon pea beans was 1.00 dry basis (db). Beans were weighed periodically until reaching a near equilibrium water content. Ten mathematical models were fitted to experimental data to characterize drying processes using the following statistical criteria: coefficient of determination $\left(R^{2}\right)$, mean relative error $(P)$, mean standard error (SE), chi-square $\left(X^{2}\right)$, and residue distribution. From the selected model and the Arrhenius equation, the effective diffusion coefficient and the activation energy used for the calculation of the enthalpy, entropy and Gibbs free energy were obtained. The Midilli was the best model to represent the kinetics of drying of pigeon pea beans. The increase in drying air temperature increases Gibs free energy and diffusivity, decreases enthalpy, and maintains the entropy negative.
\end{abstract}

Additional keywords: Cajanus cajan; effective diffusivity; enthalpy; entropy; Gibbs free energy.

\section{Resumo}

O Feijão-Guandu é uma planta comum para a agricultura familiar, sendo frequentemente utilizado como fonte de proteína para produção animal. O conhecimento da cinética de secagem e das propriedades termodinâmicas dos grãos de Feijão-Guandu (Cajanus cajan) é um estudo relevante para simulação de secagem, que visa a manter a qualidade dos grãos. Objetivou-se com o presente trabalho estimar as curvas de secagem dos grãos de Feijão Guandu, utilizando-se de modelos matemáticos, bem como determinar suas propriedades termodinâmicas. Foram utilizadas estufas de ventilação forçada para o processo de secagem. Os grãos de Feijão-Guandu tiveram como média o teor de água inicial em 1,00 base seca (b.s.), foram pesados, periodicamente, até atingirem próximo ao teor de água de equilíbrio. Dez modelos matemáticos foram ajustados aos dados experimentais para caracterizar os processos de secagem, utilizando critérios estatísticos: coeficiente de determinação $\left(R^{2}\right)$, erro médio relativo $(P)$, erro médio estimado $(S E)$, qui-quadrado $\left(X^{2}\right)$ e a distribuição de resíduos. $A$ partir do modelo selecionado e da equação de Arrhenius, foram obtidos o coeficiente de difusão efetivo e a energia de ativação usada para o cálculo da entalpia, entropia e energia livre de Gibbs. Conclui-se que Midilli foi o melhor modelo para a representação da cinética de secagem dos grãos de Feijão-Guandu e que o aumento da temperatura do ar de secagem proporciona o aumento da energia livre de Gibs e da difusividade, reduz a entalpia e mantém a entropia negativa.

Palavras-chave adicionais: Cajanus cajan; difusividade efetiva; energia livre de Gibbs; entalpia; entropia.

\section{Introduction}

Pigeon pea [(Cajanus cajan (L.) Millsp]) belongs to the Fabaceae family. It is a shrub with a good resistance to drought. Due to its pivoting radicular system, its production cycle varies from 150 to 360 days, and the grain yield is between 500 and $1,500 \mathrm{~kg} \mathrm{ha}^{-1}$. This bean plant is of great importance for countries in the tropics and subtropics, both Asian and African. It is found throughout Brazil, where its predominant production is carried out by family farming (Silva et al., 2014). 
Pigeon pea beans is a common protein bank for animal production by small farmers. This crop represents a low-cost alternative during the dry period of the year since its grains have a protein content of $21 \%$ and are rich in amino acids such as lysine, leucine, and histidine. However, they are deficient in amino acids such as methionine, cystine, and tryptophan, which is ideal for poultry and pork production (Cavalcante, 2009). The pigeon pea plant can also be used as forage for animals due to its grazing potential intercropped with grasses, such as hay, and intercropped with species used in silage both as fresh forage and for direct consumption of green grains (Paludo et al., 2012).

The pre-processing process makes it possible to maintain the quality of beans during storage for long periods (Almeida et al., 2009). Thus, the unitary operation called drying has the objective of decreasing the initial water content of the grains in order to increase the product shelf life.

Drying kinetics evaluates the mass transfer behavior between the grains and the drying agent. From this perspective of evaluation, the diffusion of water present in thin layers of grains can be inferred when subjected to certain air temperatures, surface speeds, and relative humidity of the drying air. In this sense, it is possible to make adjustments of theoretical or empirical mathematical models. Such models allow estimating the behavior of water movement inside the grain, which is represented by modeling curves (Rodovalho et al., 2015).

In addition to drying kinetics of pigeon pea grains, research on thermodynamic properties is also relevant for the development of equipment, study of adsorbed and desorbed water properties, calculation of required energy involved in the drying process, evaluation of the microstructure of food, and the study of physical and chemical phenomena that occur on the surface of grains (Corrêa et al., 2010). The effective diffusion coefficient is a thermodynamic property based on the second Fick Law, which relates the diffusion coefficient of the grain to the drying air. Thus, diffusivity is understood as the ease with which water is withdrawn from the grain into the ambient air. Its values may vary according to temperature, drying air speed, and grain composition (Morais et al., 2013).

Among thermodynamic properties, enthalpy provides a measurement of the energy variation that occurs during the interaction of water molecules with the grain structure during sorption processes. Entropy is associated with the binding or repulsion of water molecules of grain components during drying and the spatial arrangement between water and grain, characterizing the degree of order and disorder (Corrêa et al., 2017). The Gibbs free energy allows evaluating the affinity between the grain and the water. It is able to indicate if the water exiting the product during the drying process is spontaneous or not (Oliveira et al., 2013).
Considering the importance of the theoretical study of the drying process of pigeon pea beans, the objective of this study is to estimate the drying curves of pigeon pea beans using mathematical models, and to determine their thermodynamics properties.

\section{Materials and methods}

The experiment was conducted at the Laboratory of Instrumental Chemistry of the Goiano Federal Institute, campus Ceres, from March to May 2017. The grains of the cultivar Guandu 2 super $\mathrm{N}$ used in the experiment were acquired in the retail market. $250 \mathrm{~g}$ pigeon pea beans were weighed for each temperature tested. Distilled water was added in a proportion capable of increasing the water content from $11 \%$ to $20 \%$. The samples were refrigerated for four days in hermetically sealed containers.

After the wetting process, the water content of the grains on dry basis (db) was determined before and after drying using the greenhouse method at 105 $\pm 1^{\circ} \mathrm{C}$ for $24 \mathrm{~h}$ in triplicates (Brasil, 2009).

The samples were packed in petri dishes $(50 \mathrm{~g}$ per replicate), and submitted to four temperatures in a BOD (Biochemical Oxygen Demand) chamber. During the drying process, the samples were weighed at 20minute intervals using a digital analytical scale.

The determination of the water decrease rate (WDR) of the pigeon pea grains was performed by the equation (1):

WRD $=\frac{\mathrm{Ma}_{0}-\mathrm{Ma}_{\mathrm{I}}}{\mathrm{Dm}\left(\mathrm{t}_{\mathrm{I}}-\mathrm{t}_{0}\right)}$

Wherein: WDR is the water decrease rate $(\mathrm{g}$ of water $\mathrm{g}^{-1}$ of dry matter min $\left.^{-1}\right), \mathrm{Ma}_{0}$ is the mass of the total previous water $(\mathrm{g}), \mathrm{Ma}_{\mathrm{I}}$ is the mass of total current water $(\mathrm{g}), D \mathrm{Dm}$ is the dry matter $(\mathrm{g}), \mathrm{t}_{0}$ is the total previous drying time $(h)$, and $t_{I}$ is the total current drying time (h).

In order to determine the calculation of the water content ratios $(R X)$ of pigeon pea beans during the drying process, the equation (2) was used:

$R X=\frac{(X-X e)}{(X i-X e)}$

Wherein: RX is the water content ratio (dimensionless), $X$ is the grain water content $\left(\mathrm{kg}^{-1}\right.$ of water $\mathrm{kg}^{-1}$ of dry matter), $\mathrm{Xe}$ is the equilibrium water content of the grain ( $\mathrm{kg}$ of water $\mathrm{kg}^{-1}$ dry matter), and $\mathrm{Xi}$ is the initial water content of the pigeon pea bean ( $\mathrm{kg}$ of water $\mathrm{kg}^{-1}$ of dry matter).

Ten empirical models of experimental data related to drying kinetics were used to represent drying curves. The models are used to determine the drying of yellow lantern chili (Silva et al., 2016) and the drying of sunflower seeds (Smaniotto et al., 2017) (Table 1). The fittings were performed by non-linear regression using the Gauss-Newton interaction. The Statistica software version 7.0 was used to fit the models. 
Table 1 - Non-linear regression models used to predict drying phenomena of pigeon pea beans fitted to water content ratio data.

\begin{tabular}{|c|c|c|}
\hline Model name & Equations & \\
\hline Diffusion Approach (Kassem, 1998) & $R X=a \exp (-k t)+(1-a) \exp (-k b t)$ & $(3$ \\
\hline Two Terms (Henderson, 1974) & $R X=a \exp (-k t)+b \exp (-k 1 t)$ & (4) \\
\hline Henderson and Pabis (Henderson \& Pabis, 1961) & $R X=a \exp (-k t)$ & $(5$ \\
\hline Logarithmic (Yagcioglu et al., 1999) & $R X=a \exp (-k t)+b$ & \\
\hline Midilli (Midilli et al., 2002) & $R X=a \exp (-k t b)+n t$ & \\
\hline Modified Midili (Ghazanfari et al., 2006) & $R X=\exp (-k t n)+a t$ & \\
\hline Newton (Lewis, 1921) & $R X=\exp (-k t)$ & \\
\hline Page (Page, 1949) & $R X=\exp (-k t n)$ & \\
\hline Verma (Verma et al., 1985) & $R X=a \exp (-k t)+(1-a) \exp (-k 1 t)$ & (11) \\
\hline Wang Singh (Wang \& Sing, 1978) & $R X=1+(a t)+(b(t 2))$ & \\
\hline
\end{tabular}

$\mathrm{RX}$ - grain water content ratio (dimensionless); $\mathrm{t}$ - drying time in hours; $\mathrm{k}$ - drying coefficient; $\mathrm{a}, \mathrm{b}, \mathrm{c}$ and $\mathrm{d}$ - constants of the models.

The statistical criteria used to select the mathematical model that represents the drying kinetics of pigeon pea beans were the significance of the model coefficients by the $t$ test at a 0.05 level of significance, the magnitude of the coefficient of determination $\left(R^{2}\right)$ fitted by the model, relative mean error $(P)$ (Equation 13), mean standard error (SE) (Equation 14), calculated Chi-square $\left(X^{2}\right)$ (Equation 15), and distribution of residue behavior. The selection of the mathematical model was performed when the $\mathrm{R}^{2}$ was the closest to the unit, $\mathrm{P}$ less than $10 \%$, SE closer to zero, the lowest value of $X^{2}$ (calculated according to the level of significance), and the degrees of freedom (DF). The analysis of the residue behavior generated by the model was considered random when there was a uniform distribution of data obtained during drying.

$\mathrm{P}=\frac{100}{\mathrm{n}} \sum^{\mathrm{n}}\left(\frac{|\mathrm{Y}-\hat{\mathrm{Y}}|}{\mathrm{Y}}\right)$

$S E=\sqrt{\frac{\sum_{i=1}^{n}(Y-\hat{Y})^{2}}{D F}}$

$X^{2}=\sum_{i=1}^{n} \frac{(Y-\hat{Y})^{2}}{D F}$

$r=\left(\frac{3 V g}{4 \pi}\right)^{1 / 3}$

Wherein: $\mathrm{Vg}$ is the grain volume $\left(\mathrm{m}^{3}\right)$; $A$ is the largest grain axis $(m)$; $B$ is the intermediate grain axis $(m) ; C$ is the smallest grain axis $(m)$, and $r$ is the equivalent radius of the sphere $(\mathrm{m})$.

From the orthogonal axes obtained, the net diffusion model was fitted to a spherical geometric shape and to the experimental data of the drying of pigeon pea beans. The effective diffusion coefficient (Def) was thus determined. This equation and the anaIytical solution for the second law of Fick considered the geometric form of the product as spherical described by the Equation (18) (Camicia et al., 2015):

$R X=\frac{X-X_{e}}{X_{i}-X_{e}}=\frac{6}{\pi^{2}} \sum_{n=1}^{\infty} \frac{1}{n^{2}} \exp \left[-\frac{n^{2} \pi^{2} D_{\text {ef }} t}{r^{2} \text { eq }}\right]$

Wherein: $\mathrm{RX}$ is the water content ratio (dimensionless) according to equation (2); $X$ - water content of the grain, $\mathrm{db} ; \mathrm{Xi}$ - initial water content of the grain, $\mathrm{db} ; \mathrm{Xe}$ equilibrium water content of the grain, $\mathrm{db}$; Def is the effective diffusion coefficient $\left(\mathrm{m}^{2} \mathrm{~s}^{-1}\right) ; \mathrm{n}$ is the number of cases (terms); $t$ is the time (s), and $r$ is the equivalent mean radius of the pigeon pea bean.

The relation between the increase in the effec-

Wherein: $P$ is the relative mean error (\%), SE is the mean standard error, $n$ is the number of cases, $Y$ is the experimental value, $\hat{Y}$ is the estimated value, DF is the degree of freedom (number of experimental observations minus the number of model coefficients), and $X^{2}$ is the Chi-square.

For the determination of diffusivity, it was necessary to estimate the volume of the pigeon bean grain $\left(\mathrm{V}_{\mathrm{g}}\right)$ previously using the Equation (16) proposed by Mohsenin (1986) by measuring the three orthogonal axes of fifty grains using a digital caliper with a $0.02 \mathrm{~mm}$ accuracy. Then, the estimated mean radius of the volume of the sphere $(r)$ was obtained by Equation (17).

$V_{g}=\pi \frac{A B C}{6}$ tive diffusion coefficient $\left(D_{\mathrm{ef}}\right)$ and the increase in the drying air temperature was performed by the Equation (19), which represents the Arrhenius model.

$\mathrm{D}_{\text {ef }}=\mathrm{D}_{0} \exp \left[-\frac{\mathrm{E}}{\mathrm{RT}}\right]$

Wherein: $D_{0}$ is the pre-exponential factor $\left(\mathrm{m}^{2} \mathrm{~s}^{-1}\right)$; $E$ is the activation energy $\left(\mathrm{J} \mathrm{mol}^{-1}\right) ; \mathrm{R}$ is the universal gas constant $\left(8.314 \mathrm{~J} \mathrm{~mol}^{-1} \mathrm{~K}^{-1}\right)$, and $\mathrm{T}$ is the absolute temperature $(\mathrm{K})$.

The thermodynamic properties of the drying of pigeon pea beans were determined by the method described by Corrêa et al. (2007). Calculations of specific enthalpy $(\Delta \mathrm{H})$ were performed using the Equation (20). The specific entropy $(\Delta S)$ was determined by the Equation (21), and the Gibbs free energy $(\Delta G)$ was determined by the Equation (22), with estimated diffusivity values.

$\Delta \mathrm{H}=\mathrm{E}-\mathrm{R} T$ 
$\Delta S=R\left[\ln \left(D_{0}\right)-\ln \left(\frac{k_{B}}{h_{p}}\right)-\ln (T)\right]$

$\Delta \mathrm{G}=\Delta \mathrm{H}-\mathrm{T} \Delta \mathrm{S}$

Wherein: $\Delta \mathrm{H}$ is the enthalpy $\left(\mathrm{J} \mathrm{mol}^{-1}\right) ; \Delta S$ is the entropy $\left(\mathrm{J} \mathrm{mol}^{-1}\right) ; \mathrm{k}_{\mathrm{B}}$ is the Boltzmann constant $\left(1.3810^{-23} \mathrm{~J} \mathrm{~K}^{-1}\right)$, and $h_{p}$ is the- Planck constant $\left(6.62610^{-34} \mathrm{~J} \mathrm{~s}^{-1}\right)$.

\section{Results and discussion}

The moisture content of pigeon pea grains had a mean of 0.25 on a dry basis (db), and decreased over the drying period to $0.13,0.12,0.09$, and 0.09 at temperatures of $30,40,50$, and $60{ }^{\circ} \mathrm{C}$, respectively (Figure $1 \mathrm{~A}$ ). The conditions studied for drying pigeon pea beans were efficient for the decrease in free and solvent wa- ter, which allows the decrease of fungal growth (Jangam et al., 2010). The high moisture content in the grains associated with high relative air humidity creates conditions for the development of fungi, and generally increases the development rate of population of some species of insects and mites, which also accelerates deterioration of stored grains. Therefore, the decrease in moisture content of grains is essential to ensure a safe storage.

The increase in the temperature of the drying air allows a greater decrease in the water in the grain (Figure 1A) due to an increase in the water potential gradient between the grain and the air. Corrêa et al. (2007) reported the same behavior for beans of the red group, Sousa et al. (2011) for forage turnip grains, and Camicia et al. (2015) for cowpea beans.
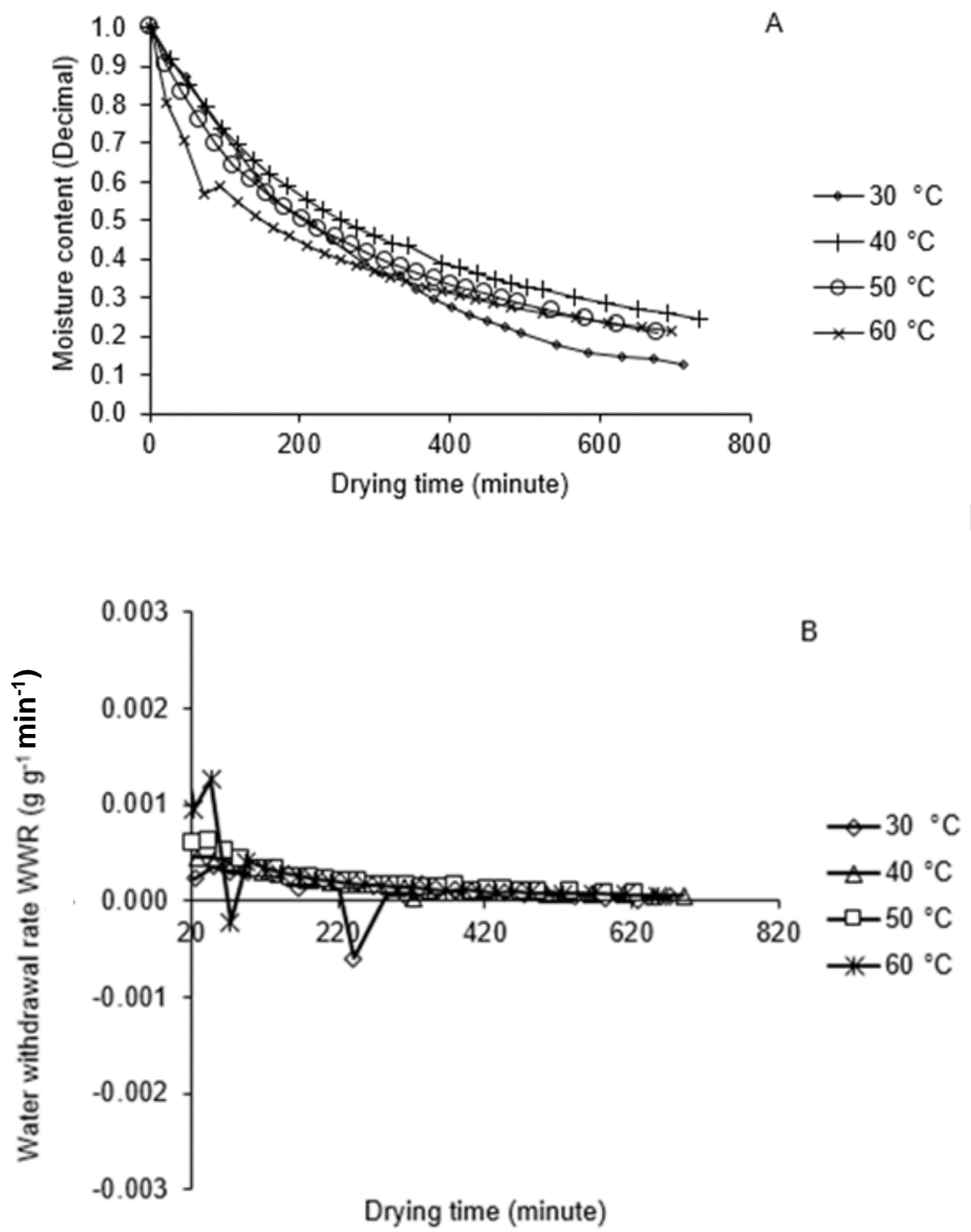

Figure $1-(A)$ - Mean values of the water ratio $(R X)$ of the bean grains (decimal) as a function of the drying time (minutes) at four air temperatures; (B) - Mean values of the water withdrawal rate (WWR) $\left(\mathrm{g} \mathrm{g}^{-1}\right.$ minute $^{-1}$ ) of the bean grains subjected to drying kinetics at different temperatures $\left(30,40,50\right.$ and $\left.60{ }^{\circ} \mathrm{C}\right)$. 
The drying times and final $R X$ values of pigeon pea grains were $14 \mathrm{~h}$ and $35 \mathrm{~min}$ and $0.24,13 \mathrm{~h}$ and $20 \mathrm{~min}$ and $0.21,12 \mathrm{~h}$ and $37 \mathrm{~min}$ and 0.22 , and $11 \mathrm{~h}$ and 52 min and 0.12 for the drying air temperatures of $30,40,50$ and $60{ }^{\circ} \mathrm{C}$, respectively (Figure $1 \mathrm{~A}$ ). According to Siqueira et al. (2012), the increase in temperature, which in the present study was from 30 to $60^{\circ} \mathrm{C}$, allows the decrease of the drying period of grains. This is because the difference between the vapor pressure of the drying air and the grain increases when temperature increases, providing a greater reduction of water content in a shorter period.

The decrease of water in the grain during the drying period (water decrease rate, WDR), showed that the highest rates of water reduction in the grain were $3,61310^{-4}, 4,72310^{-4}, 8,27210^{-4}, 1,93910^{-4} \mathrm{~g} \mathrm{~g}^{-1} \mathrm{~min}^{-1}$ for the temperatures $30,40,50$ and $60{ }^{\circ} \mathrm{C}$, respectively (Figure 1B). The WDR increased with the increase in the drying air temperature due to the excitation of water molecules, thus causing a greater vaporization. The WDR decreases continuously until it becomes stable. With the reduction of free and solvent water, the migration of water from the interior to the surface of the grain becomes slower and more difficult (Jangam et al., 2010).

At the end of drying, the water is strongly bound to the dry matter, requiring a greater amount of energy for evaporation. Thus, the drying of pigeon pea grains occurred more slowly, resulting in lower values of WDR. The increase in the temperature of the drying air provided a higher WDR of pigeon pea beans, as was observed for red beans by Correa et al. (2007) and by Resende et al. (2007). This behavior indicates that diffusion is the highest probable physical mechanism governing water movement in thin layers (Rafiee et al., 2009).

Table 2 shows the statistical criteria of model fittings to the experimental data obtained from the drying of pigeon pea beans. The models presented a $\mathrm{R}^{2}$ value close to the magnitude. The modified Midilli and the Midilli models presented a relative mean error $(P)$ below $10 \%$ for drying air temperatures 40,50 and $60 \stackrel{\circ}{ } \mathrm{C}$, indicating an appropriate fitting for this criterion (Mohapatra; Rao, 2005). Among the models evaluated, the Midilli presented the lowest values for mean standard error (SE).

Table 2 - Values of the coefficient of determination $\left(R^{2}\right)$, relative mean error (RE), estimated mean error (EE), calculated chi-square $\left(\mathrm{X}^{2}\right)$ and distribution of residues (Dist), as criteria for adjusting the models to the experimental data of the drying of the pigeon pea, obtained in the air temperatures of $30,40,50$ and $60^{\circ} \mathrm{C}$. * $\mathrm{B}$ : Biased distribution of residues; R: Random distribution of residues.

\begin{tabular}{|c|c|c|c|c|c|c|c|c|c|c|}
\hline \multirow{2}{*}{$\mathrm{T}\left({ }^{\circ} \mathrm{C}\right)$} & \multicolumn{5}{|c|}{ Diffusion Approach } & \multicolumn{5}{|c|}{ Two Terms } \\
\hline & $R^{2}(\%)$ & $\mathrm{RE}(\%)$ & EE & $x^{2}$ & DIST & $R^{2}(\%)$ & $\mathrm{RE}(\%)$ & EE & $x^{2}$ & DIST* $^{*}$ \\
\hline 30 & 96.38 & 13.0317 & 0.0713 & 0.0051 & B & 96.39 & 13.007 & 0.0712 & 0.0051 & B \\
\hline 40 & 99.85 & 2.3673 & 0.0111 & 0.0001 & $\mathrm{R}$ & 99.85 & 2.3625 & 0.0111 & 0.0001 & $\mathrm{R}$ \\
\hline 50 & 99.92 & 1.7267 & 0.0078 & 0.0001 & $\mathrm{R}$ & 99.1 & 4.9316 & 0.0266 & 0.0007 & B \\
\hline 60 & 85.90 & 19.5474 & 0.0932 & 0.0087 & B & 99.85 & 3.2177 & 0.0269 & 0.0007 & B \\
\hline & \multicolumn{5}{|c|}{ Henderson and Pabis } & \multicolumn{5}{|c|}{ Logarithmic } \\
\hline 30 & 96.39 & 13.0371 & 0.0712 & 0.0051 & B & 96.52 & 13.3331 & 0.0699 & 0.0049 & B \\
\hline 40 & 98.70 & 6.5443 & 0.0333 & 0.0011 & B & 99.81 & 2.6329 & 0.0126 & 0.0002 & $\mathrm{R}$ \\
\hline 50 & 98.63 & 6.1714 & 0.0331 & 0.0011 & $\mathrm{~B}$ & 99.74 & 2.9599 & 0.0149 & 0.0002 & B \\
\hline 60 & 94.30 & 9.9018 & 0.0611 & 0.0037 & B & 97.74 & 5.5722 & 0.0391 & 0.0015 & B \\
\hline & \multicolumn{5}{|c|}{ Midilli } & \multicolumn{5}{|c|}{ Modified Midili } \\
\hline 30 & 98.17 & 13.4786 & 0.0699 & 0.0049 & $\mathrm{R}$ & 96.52 & 13.4854 & 0.0699 & 0.0049 & $\mathrm{R}$ \\
\hline 40 & 99.83 & 2.5122 & 0.012 & 0.0001 & $\mathrm{R}$ & 99.82 & 2.5245 & 0.0122 & 0.0001 & $\mathrm{R}$ \\
\hline 50 & 99.88 & 1.9728 & 0.0098 & 0.0001 & $\mathrm{R}$ & 99.88 & 1.9833 & 0.01 & 0.0001 & $\mathrm{R}$ \\
\hline 60 & 99.91 & 2.4182 & 0.0269 & 0.0007 & $\mathrm{R}$ & 98.96 & 2.4074 & 0.0269 & 0.0007 & $\mathrm{R}$ \\
\hline & \multicolumn{5}{|c|}{ Newton } & \multicolumn{5}{|c|}{ Page } \\
\hline 30 & 96.38 & 13.0317 & 0.0713 & 0.0051 & $\mathrm{~B}$ & 96.43 & 12.9186 & 0.0707 & 0.0051 & $B$ \\
\hline 40 & 97.81 & 9.0277 & 0.0431 & 0.0019 & B & 99.65 & 3.1869 & 0.0172 & 0.0003 & B \\
\hline 50 & 97.30 & 9.5985 & 0.0463 & 0.0021 & B & 99.82 & 1.9526 & 0.0117 & 0.0001 & $\mathrm{R}$ \\
\hline 60 & 85.90 & 19.5476 & 0.0932 & 0.0087 & B & 98.94 & 2.4794 & 0.027 & 0.0007 & $\mathrm{R}$ \\
\hline & \multicolumn{5}{|c|}{ Verma } & \multicolumn{5}{|c|}{ Wang Singh } \\
\hline 30 & 96.51 & 13.2221 & 0.0701 & 0.0049 & B & 96.06 & 15.7037 & 0.0743 & 0.0055 & B \\
\hline 40 & 99.85 & 2.3673 & 0.0111 & 0.0001 & $\mathrm{R}$ & 98.73 & 6.4281 & 0.0328 & 0.0011 & B \\
\hline 50 & 99.92 & 1.7267 & 0.0078 & 0.0001 & $\mathrm{R}$ & 97.7 & 8.8034 & 0.0443 & 0.002 & B \\
\hline 60 & 97.47 & 6.5696 & 0.041 & 0.0017 & B & 87.71 & 17.0272 & 0.0888 & 0.0079 & B \\
\hline
\end{tabular}

As for the calculated $\mathrm{X}^{2}$, all models presented low values, also suggesting an adequate fitting since the lower the Chi-square value, the better the model fitting (Draper; Smith, 1998). Thus, the modified Midilli because they presented the lowest values of $x^{2}$ calculated in relation to the other fitted models.

Regarding the behavior of residues, the Midilli and the Midilli models presented satisfactory results model presented a random distribution for the temperatures $30,40,50$ and $60^{\circ} \mathrm{C}$, as can be observed in 
Table 2 and Figure 2. However, the Handerson and Pabis model presented a biased distribution for the temperatures 40,50 and $60^{\circ} \mathrm{C}$ (Table 2 and Figure 3). By means of statistical criteria, the Midilli is the most recommended model to represent the drying kinetics of pigeon pea beans at the temperatures 30, 40, 50 and $60{ }^{\circ} \mathrm{C}$ (Table 2 and Figure 2). Resende et al. (2010) also recommended the Midilli model for Adzuki bean grains subjected to drying at $30,40,50,60$ and $70{ }^{\circ} \mathrm{C}$.
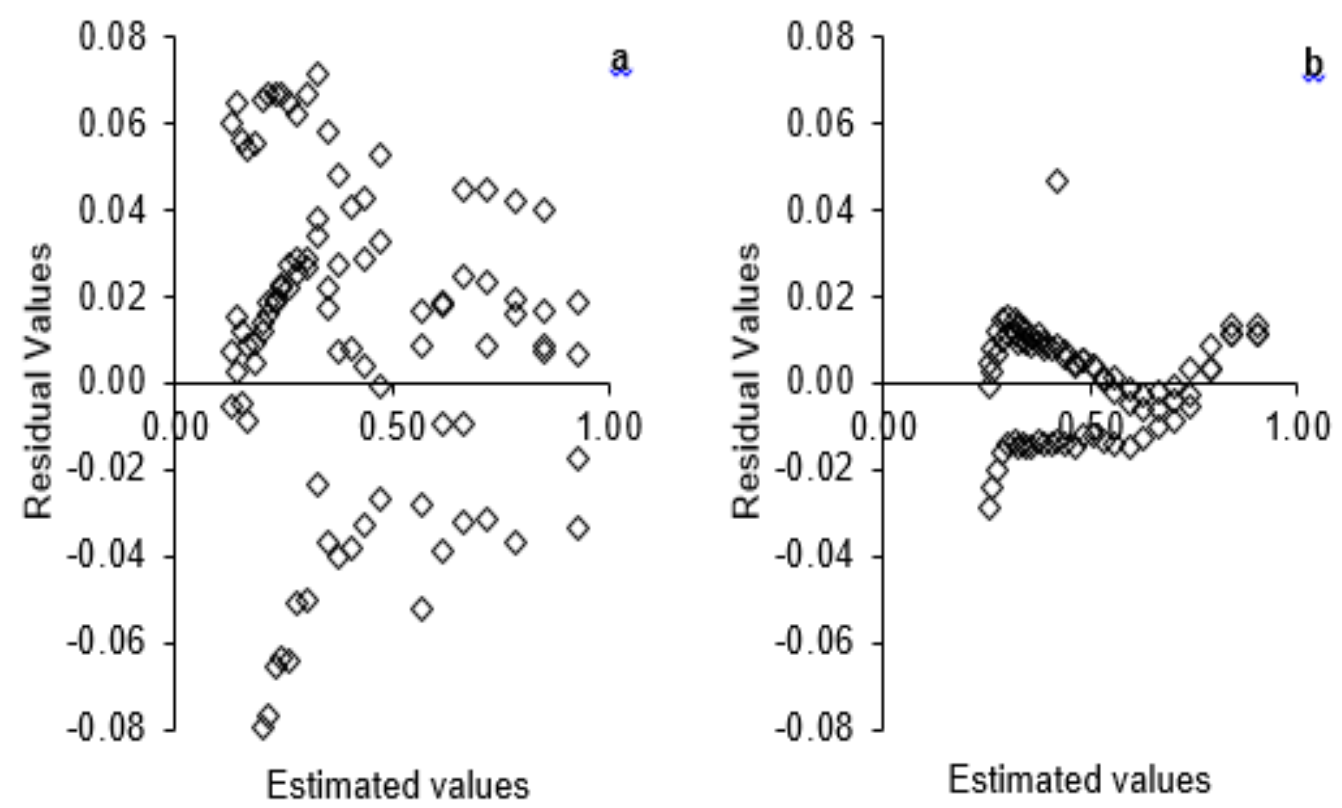

Estimated values
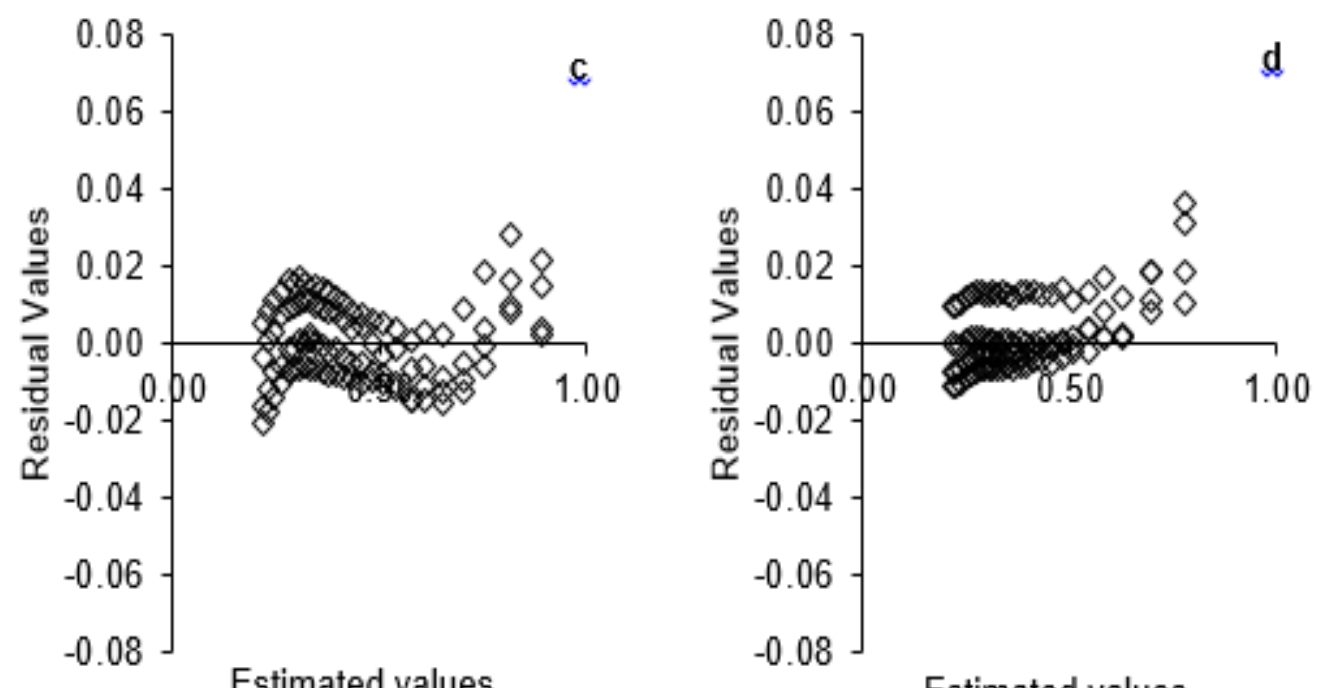

Estimated values

Figure 2. Distribution of the residues by the Midilli model for the pigeon pea at the drying air temperatures of 30 (a), 40 (b), 50 (c) and $60^{\circ} \mathrm{C}(\mathrm{d})$.

For pigeon pea grains, the Handerson and Pabis model presented statistical criteria unfavorable for the representation of drying phenomena (Table 2 and Figure 3). In the studies by Morais et al. (2013), the Henderson and Pabis model presented the best fittings for cowpea grains at temperatures 25, 35, 45 and $55^{\circ} \mathrm{C}$ using an experimental drier. These differences in the recommendation of empirical models are probably related to drying conditions. 

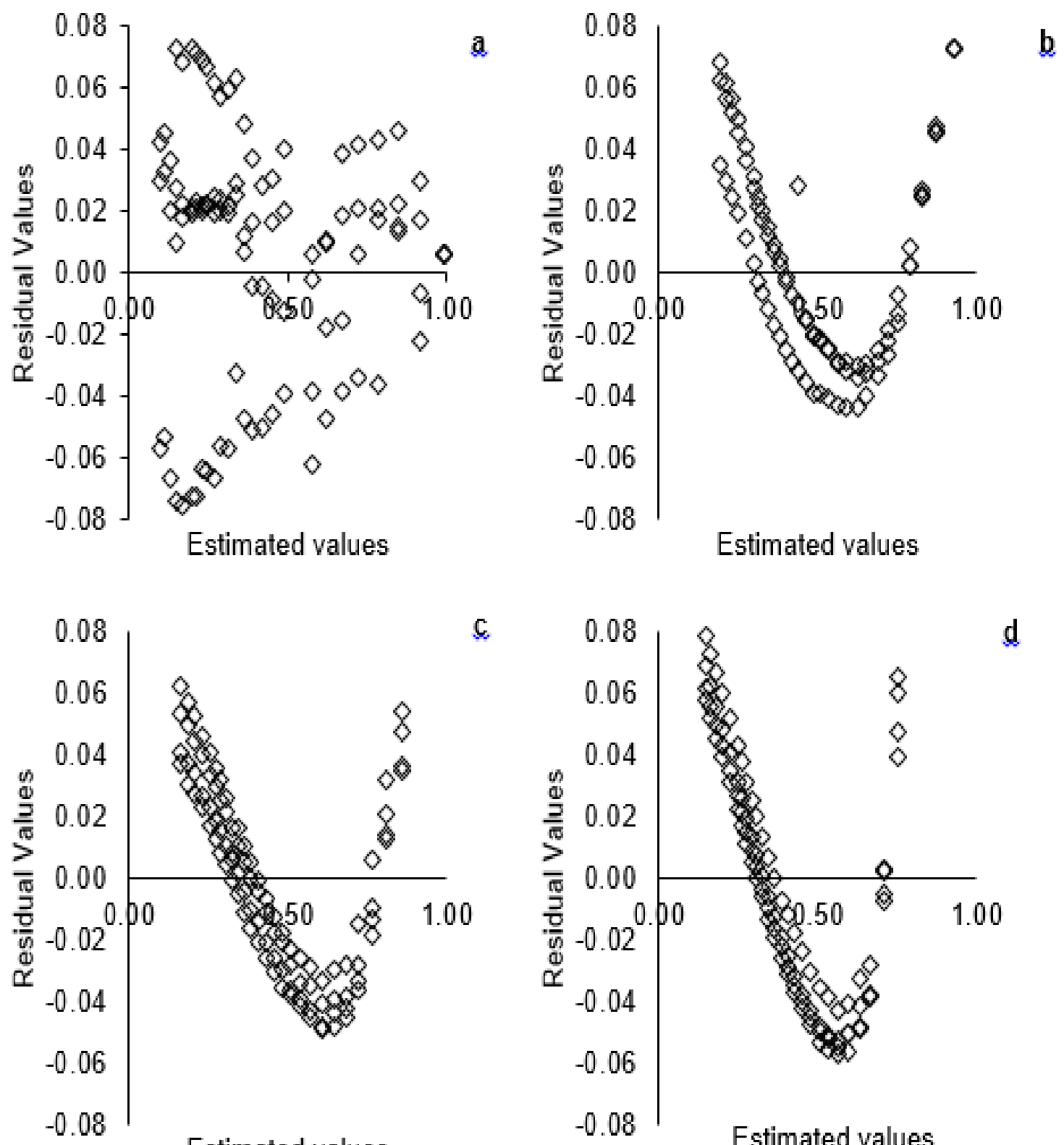

C

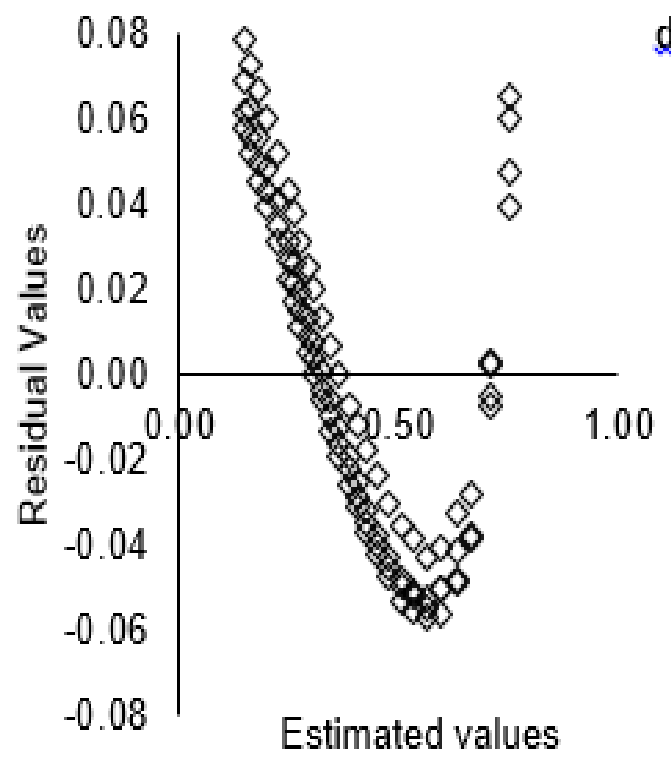

Figure 3 - Distribution of the residues by the Henderson and Pabis model for the pigeon pea at the drying air temperatures of $30(\mathrm{a}), 40(\mathrm{~b}), 50(\mathrm{c})$ and $60^{\circ} \mathrm{C}(\mathrm{d})$.

According to Souza et al. (2011), the empirical specimens are fitted based on data obtained by laboratory experiments and external conditions (temperature and moisture content ratio). In this case, the fitted model becomes unique for the particular type of grain and the experimental conditions of drying (Resende et al., 2008).

Table 3 shows that the Midilli, modified Midilli, Page and Verma models showed an increase in the coefficient "k" with the increase in temperature. This indicates that effective diffusivity controls the entire drying process during the decreasing period, as Araújo et al. (2017) reported. The coefficient "k" can be used as an approximation to characterize the effects of temperature. It is related to diffusivity during the drying process (Barbalis \& Belessiotis, 2004). The coefficients "a, b n, and k1" of the models, fitted to experimental data obtained from pigeon pea beans, did not present a clear tendency of behavior with the increase in temperature. They can be treated as empirical variables in this case (Table 3 ).

During drying, the effective diffusion coefficient $\left(D_{\mathrm{ef}}\right)$ of pigeon pea grains ranged from $1,95010^{-8}$ to $2,99910^{-8} \mathrm{~m}^{2} \mathrm{~s}^{-1}$ with the increase in drying air temperature, which is common for most agricultural products (Figure 4). The results are consistent with those reported by Jangam et al. (2010), who analyzed grains and some plant materials that presented $D_{\text {ef }}$ values between $10^{-13}$ and $10^{-7}$. 
Table 3 - Parameters of the models adjusted to the pigeon pea grains drying.

\begin{tabular}{|c|c|c|c|c|c|c|}
\hline Model & $\mathrm{T}\left({ }^{\circ} \mathrm{C}\right)$ & $\mathrm{a}$ & $b$ & $\mathrm{n}$ & $\mathrm{k}$ & $\mathrm{k} 1$ \\
\hline \multirow{4}{*}{$\begin{array}{l}\text { Diffusion } \\
\text { Approach }\end{array}$} & 30 & $1.1874^{\mathrm{ns}}$ & $0.9997^{\text {ns }}$ & & $0.0032^{\text {ns }}$ & \\
\hline & 40 & $0.5071^{*}$ & $0.1753^{\star}$ & & $0.0056^{\star}$ & \\
\hline & 50 & $0.3519^{*}$ & $0.1620^{\star}$ & & $0.0103^{*}$ & \\
\hline & 60 & $1.0000^{*}$ & $1.0000^{*}$ & & $0.0033^{*}$ & \\
\hline \multirow{4}{*}{ Two Terms } & 30 & $0.0088^{*}$ & $0.9907^{*}$ & & $0.8999^{*}$ & $0.0032^{*}$ \\
\hline & 40 & $0.4903^{*}$ & $0.5144^{*}$ & & $0.0059^{\star}$ & $0.0010^{*}$ \\
\hline & 50 & $0.1224^{*}$ & $0.8771^{*}$ & & $0.8950^{\mathrm{ns}}$ & $0.0024^{*}$ \\
\hline & 60 & $0.3882^{*}$ & $0.6072^{*}$ & & $0.0233^{*}$ & $0.0016^{*}$ \\
\hline \multirow{4}{*}{$\begin{array}{l}\text { Henderson and } \\
\text { Pabis }\end{array}$} & 30 & $0.9934^{*}$ & & & $0.0032^{*}$ & \\
\hline & 40 & $0.9267^{*}$ & & & $0.0022^{*}$ & \\
\hline & 50 & $0.9085^{\star}$ & & & $0.0026^{\star}$ & \\
\hline & 60 & $0.7947^{*}$ & & & $0.0024^{*}$ & \\
\hline \multirow{4}{*}{ Logarithmic } & 30 & $0.9469^{*}$ & $0.0687^{*}$ & & $0.0039^{*}$ & \\
\hline & 40 & $0.7765^{\star}$ & $0.2152^{*}$ & & $0.0039^{\star}$ & \\
\hline & 50 & $0.7716^{*}$ & $0.1996^{*}$ & & $0.0045^{\star}$ & \\
\hline & 60 & $0.6657^{*}$ & $0.2450^{\star}$ & & $0.0063^{\star}$ & \\
\hline \multirow{4}{*}{ Midilli } & 30 & $1.0091^{*}$ & $0.0000^{\mathrm{ns}}$ & $1.0181^{*}$ & $0.0033^{\text {ns }}$ & \\
\hline & 40 & $1.0093^{*}$ & $0.0001^{*}$ & $0.8769^{*}$ & $0.0059^{\star}$ & \\
\hline & 50 & $1.0087^{*}$ & $0.0000^{*}$ & $0.7838^{*}$ & $0.0111^{*}$ & \\
\hline & 60 & $1.0034^{*}$ & $0.0000^{\mathrm{ns}}$ & $0.5518^{*}$ & $0.0447^{*}$ & \\
\hline \multirow{4}{*}{ Modified Midili } & 30 & $0.0000^{\text {ns }}$ & & $1.037^{*}$ & $0.0029^{*}$ & \\
\hline & 40 & $0.0001^{*}$ & & $0.8967^{*}$ & $0.0053^{*}$ & \\
\hline & 50 & $0.0000^{*}$ & & $0.8002^{*}$ & $0.0101^{*}$ & \\
\hline & 60 & $0.0000^{\text {ns }}$ & & $0.5556^{*}$ & $0.0436^{*}$ & \\
\hline \multirow{4}{*}{ Newton } & 30 & & & & $0.0033^{*}$ & \\
\hline & 40 & & & & $0.0024^{*}$ & \\
\hline & 50 & & & & $0.0029^{*}$ & \\
\hline & 60 & & & & $0.0033^{*}$ & \\
\hline \multirow{4}{*}{ Page } & 30 & & & $0.9492^{*}$ & $0.0044^{*}$ & \\
\hline & 40 & & & $0.7710^{*}$ & $0.0092^{*}$ & \\
\hline & 50 & & & $0.7329^{*}$ & $0.0135^{\star}$ & \\
\hline & 60 & & & $0.5305^{*}$ & $0.0485^{\star}$ & \\
\hline \multirow{4}{*}{ Verma } & 30 & $0.0292^{\text {ns }}$ & & & $-0.0008^{\mathrm{ns}}$ & $0.0036^{*}$ \\
\hline & 40 & $0.4928^{\star}$ & & & $0.0009^{*}$ & $0.0056^{*}$ \\
\hline & 50 & $0.6480^{*}$ & & & $0.0016^{*}$ & $0.0103^{*}$ \\
\hline & 60 & $0.7240^{*}$ & & & $0.0021^{*}$ & $1.0000^{*}$ \\
\hline \multirow{4}{*}{ Wang Singh } & 30 & $-0.0027^{\star}$ & $0.0000^{*}$ & & & \\
\hline & 40 & $-0.0023^{*}$ & $0.0000^{*}$ & & & \\
\hline & 50 & $-0.0027^{\star}$ & $0.0000^{\star}$ & & & \\
\hline & 60 & $-0.0031^{*}$ & $0.0000^{*}$ & & & \\
\hline
\end{tabular}

\footnotetext{
${ }^{*}$ Significant at $5 \%$ probability by $\mathrm{t}$-test; ${ }^{\text {ns }}$ - Not significant at $5 \%$ probability by t test
} 


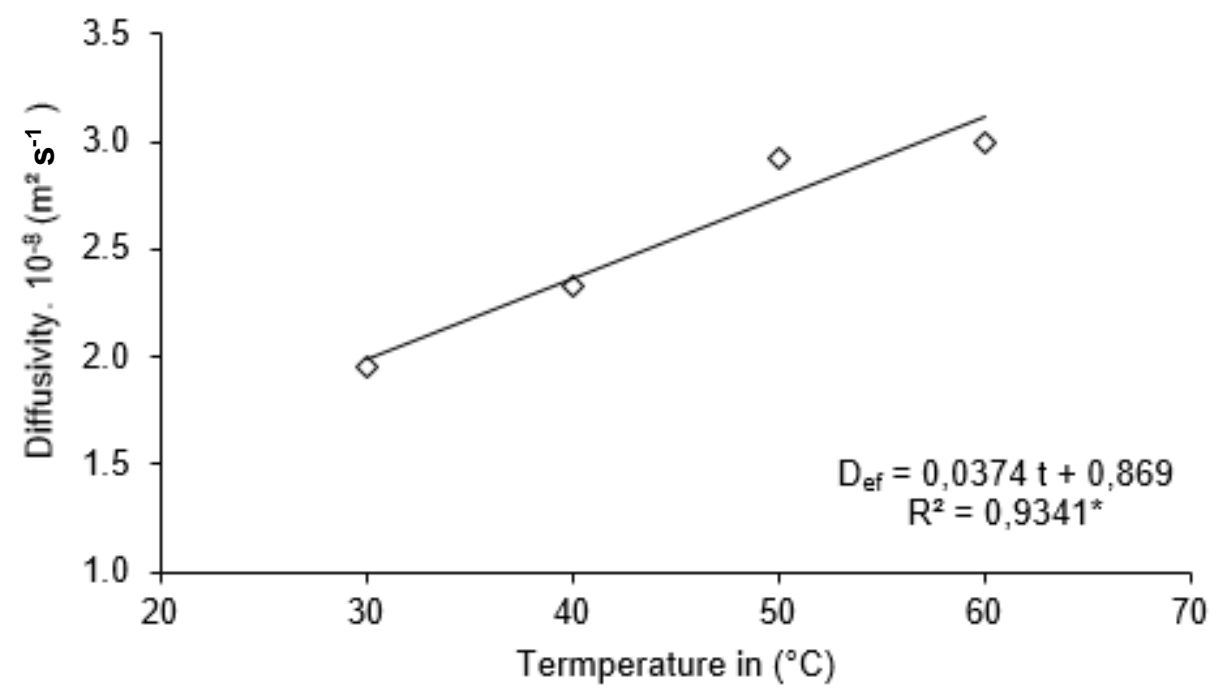

Figure 4 - Effective diffusivity (Def) estimated for pigeon pea at different drying air temperatures

Camicia et al. (2015) verified that, during the drying of the cowpea grains, the coefficients of effective diffusion presented magnitudes from $5.04710^{-11} \mathrm{~m}^{2} \mathrm{~s}^{-1}$ to $12.01110^{-11} \mathrm{~m}^{2} \mathrm{~s}^{-1}$ for the temperatures 30 to $50^{\circ} \mathrm{C}$. When drying bean grains at 35 and $45^{\circ} \mathrm{C}$, Resende et al. (2008) found values ranging from $2.4110^{-9}$ to 4.83 $10^{-9} \mathrm{~m}^{2} \mathrm{~s}^{-1}$ for red beans and from $1.3910^{-9}$ to $1.5310^{-9}$ $\mathrm{m}^{2} \mathrm{~s}^{-1}$ for black beans. This is due to the increase in the diffusion coefficient and the increase in the temperature of drying air.

The value of the pre-exponential factor $\left(D_{0}\right)$ obtained by the Ahrrenius equation was $2.49410^{-6}$, while the activation energy $\left(E_{a}\right)$ for the liquid diffusion model of pigeon pea bean was $12,139.97 \mathrm{~J} \mathrm{~mol} \mathrm{~K}^{-1}$.
For Camicia et al. (2015) and Corrêa et al. (2007), the activation energy of grains of different genera can vary between 12.7 and $110 \mathrm{~J} \mathrm{~mol} \mathrm{k}^{-1}$. In drying processes, the lower the activation energy, the greater the water diffusivity in the product. The activation energy is the minimum value required for the diffusion process to occur (Reis et al., 2011).

The determination of thermodynamic properties can be seen in Table 4 . The enthalpy values $(\Delta \mathrm{H})$ decreased from $9,619.58$ to $9,370 \mathrm{~J} \mathrm{~mol} \mathrm{k}^{-1}$ with the increase in drying temperature from 30 to $60^{\circ} \mathrm{C}$. This process indicates the need for less energy to remove the water bound to the grain during the drying period, as evaluated by Araújo et al. (2017) for peanuts.

Table 4 - Thermodynamic properties of enthalpy $(\Delta \mathrm{H})$, entropy $(\Delta S)$ and free energy of Gibs $(\Delta \mathrm{G})$ obtained by drying the beans of Guandu beans at different drying air temperatures.

\begin{tabular}{lccc}
\hline $\mathrm{T}\left({ }^{\circ} \mathrm{C}\right)$ & $\Delta \mathrm{H}\left(\mathrm{J} \mathrm{mol} \mathrm{K}^{-1}\right)$ & $\Delta \mathrm{S}\left(\mathrm{J} \mathrm{mol} \mathrm{K}^{-1}\right)$ & $\Delta \mathrm{G}\left(\mathrm{J} \mathrm{mol} \mathrm{K}^{-1}\right)$ \\
\hline 30 & $9,619.58$ & -352.31 & $116,422.06$ \\
40 & $9,536.44$ & -352.58 & $119,946.51$ \\
50 & $9,453.30$ & -352.84 & $123,473.61$ \\
60 & $9,370.16$ & -353.09 & $127,003.28$ \\
$\mathrm{R}^{2}(\%)$ & $99.99^{*}$ & $99.99^{\star}$ & $99.99^{\star}$ \\
\hline
\end{tabular}

${ }^{*}$ Significant at $5 \%$ of probability by $t$ test.

The value of entropy $(\Delta S)$ ranged from -352.31 to -353.09 for the temperatures $30,40,50$ and $60^{\circ} \mathrm{C}$. Jideani \& Mptokawane (2009) observed that entropy tends to decrease with the increase in temperature. When temperature decreases, there is less excitation of water molecules. Thus, degree of order between the water and the grain system increases. Negative values of entropy can be attributed to the existence of chemical adsorption or structural modifications of grains during the drying process (Moreira et al., 2008).

The Gibs free energy values increased
$(116,422.06,119,946.51,123,473.61$ and $127,003.28$ $\left.\mathrm{J} \mathrm{mol} \mathrm{K}{ }^{-1}\right)$ as the temperature increased $(30,40,50$, $60^{\circ} \mathrm{C}$ ). This behavior is expected since the drying process was not spontaneous. The samples were initially in an environment with a higher relative humidity (harvest), and were later subjected to a lower relative humidity (drying). As the $\Delta G$ values increased with the increase in temperature, the values of $\Delta \mathrm{H}$ and $\Delta \mathrm{S}$ decreased.

It is worth noting that the knowledge of thermodynamic properties in drying processes of agricul- 
tural products is an important source of information for designing drying equipment, calculating the energy required in this process, studying the properties of adsorbed water, evaluating the micro-structure of food, and studying the physical phenomena that occur on the surface of agricultural products (Corrêa et al., 2010).

\section{Conclusion}

The model proposed by Midilli best represented the drying kinetics of pigeon pea grains at 30 , 40,50 and $60^{\circ} \mathrm{C}$.

The enthalpy values $(\Delta \mathrm{H})$ decreased from $9,619.58$ to $9,370.16 \mathrm{~J} \mathrm{~mol} \mathrm{~K}^{-1}$ with the increase in drying temperature from 30 to $60^{\circ} \mathrm{C}$

The value of entropy $(\Delta S)$ ranged from $352.31 \mathrm{~J} \mathrm{~mol} \mathrm{~K} \mathrm{~K}^{-1}$ to $-353.09 \mathrm{~J} \mathrm{~mol} \mathrm{~K} \mathrm{~K}^{-1}$ at the temperatures $30,40,50$ and $60^{\circ} \mathrm{C}$.

The Gibs free energy values increased $\left(116,422.06 \mathrm{~J} \mathrm{~mol} \mathrm{~K} \mathrm{~K}^{-1}, 119,946.51 \mathrm{~J}\right.$ mol $\mathrm{K}^{-1}$, $123,473.61$ and $127,003.28 \mathrm{~J} \mathrm{~mol} \mathrm{~K}^{-1}$ ) as the temperature increased $\left(30,40,50,60^{\circ} \mathrm{C}\right)$.

\section{References}

Almeida DP, Resende O, Costa LM, Mendes UC, Sales JF (2009) Cinética de secagem do Feijão Adzuki (Vigna angularis). Global Science and Technology 2(1):72-83.

Araújo WD, Goneli ALD, Corrêa PC, Hartmann Filho CP, Martins EAS (2017) Modelagem matemática da secagem dos frutos de amendoim em camada delgada. Revista Ciência Agronômica 48(3):448-457.

Barbalis SJ, Belessiotis VG (2004) Influence of the conditions on the drying constants and moisture diffusivity during the thin-layer drying of figs. Journal of Food Engineering 65:449-458p.

Brasil. Ministério da Agricultura e Reforma Agrária (2009) Regras para análise de sementes. Brasília, DF.

Camicia RGM, Christ D, Coelho SEM, Camicia RFD (2015) Modelagem do processo de secagem de sementes de Feijão-Caupi. Revista Caatinga 28(3):206-214.

Cavalcante ANR (2009) Orientações técnicas para a formação de bancos de sementes de plantas forrageiras para agricultores familiares. Embrapa caprinos e ovinos: $14 p$.

Corrêa PC, Baptestini FM, Vanegas JDB, Leite R, Botelho FM, Oliveira GHH (2017) Kinetics of water sorption of damaged bean grains: Thermodynamic properties. Revista Brasileira de Engenharia Agrícola e Ambiental 21(8):556-561.

Corrêa PC, Oliveira GHH, Botelho FM, Goneli LD, Carvalho FB (2010) Modelagem matemática e determinação das propriedades termodinâmicas do café (Coffea arabica L.) durante o processo de secagem. Revista Ceres 57(5):595-601.
Corrêa PC, Resende O, Martinazzo AP, Goneli ALD, Botelho FM (2007) Modelagem matemática para a descrição do processo de secagem do feijão (Phaseolus vulgaris L.) em camadas delgadas. Engenharia Agrícola 27(2):501-510.

Draper NR, Smith H (1998) Applied regression analysis. New York: John Wiley \& Sons, 712p.

Ghazanfari A, Emami S, Tabil LG, Panigrahi S. (2006) Thin-Layer Drying of Flax Fiber: In: Modelling Drying Process Using Semi-Theoretical and Empirical Models. Drying Technology 24(1):1637-1642.

Henderson SM (1974) Progress in developing the thin layer drying equation. Transactions of the ASAE 17(6):1167-1168.

Henderson SM, Pabis S (1961) Grain drying theory. Temperature effect on drying coefficient. Journal of Agricultural Engineering Research 6:169- 174.

Jangam SV, Law CL, Mujumdar (2010) Drying of foods, vegetables and fruits. Singapore: National University of Singapore, 232p.

Jideani V, Mpotokwane SM (2009) Modeling of water absorption of Botswana Bambara varieties using Peleg's equation. Journal of Food Engineering 92(2):182- 188 .

Kassem AS (1998) Comparative studies on thin layer dryingmodels for wheat. Proceedings of the 13th International Congress on Agricultural Engineering 6:2-6.

Lewis WK (1921) The drying of solid materials. Journal Industrial Engineering 13(5):427-33.

Midilli A, Kucuk H, Za Y (2002) A new model for single-layer drying. Drying technology 20(7):1503-1513.

Mohapatra D, Rao PS (2005) A thin layer drying model of parboiled wheat. Journal of Good Engineering 66 (4):513-518.

Mohsenin NN (1986) Physical properties of plant and animal materials. New York: Gordon and Breach Publishers. 841p.

Morais SJS, Devilla IA, Ferreira DA, Teixeira IR (2013) Modelagem matemática das curvas de secagem e coeficiente de difusão de grãos de Feijão-Caupi. Revista Ciência Agronômica 44(3):455-463.

Moreira R, Chenlo F, Torres MD, Vallejo N (2008) Thermodynamic analysis of experimental sorption isotherms of loquat and quince fruits. Journal of Food Engineering 88(4):514-521. 
Oliveira DEC, Resende O, Smaniotto TAS, Sousa KA, Campos RC (2013) Propriedades termodinâmicas de grão de milho para diferentes teores de água de equilíbrio. Revista Pesquisa Agropecuária Tropical 43(1):50-56.

Page, G.E. Factors influencing the maximum rates of air drying shelled corn in thin layers. Indiana: 1949. Dissertação (Mestrado).Purdue University, USA.

Paludo A, Santos NF, Moreira TSO, Oliveira WL, Silva MAP (2012) Feijão-Guandu em três alturas de corte na alimentação de ruminantes. Revista eletrônica Nutritime 9(5):1981-1994.

Rafiee SH, Keyhani A, Sharifi M, Jafari A, Mobli H, Tabatabaeefar A (2009) Thin Layer Drying Properties of Soybean (Viliamz Cultivar). Journal of Agricultural Science and Technology 11(3):289-300.

Reis RC, Barbosa LS, Lima ML, Reis JS, Devilla IA, Ascheri DPR (2011) Modelagem matemática da secagem da pimenta cumari do Pará. Revista Brasileira de Engenharia Agrícola e Ambiental 15(4):347-353.

Resende O, Corrêa PC, Goneli ALD, Botelho FM, Rodrigues SR (2008) Modelagem matemática do processo de secagem de duas variedades de feijão (Phaseolus vulgaris L.). Revista Brasileira de Produtos Agroindustriais 10(1):17-26.

Resende O, Corrêa PC, Jaren C, Moure AJ (2007) Bean moisture diffusivity and drying kinetics: a comparison of the liquid diffusion model when taking into account and neglecting grain shrinkage. Spanish Journal of Agricultural Research 5(1):51-58.

Resende O, Ferreira LU, Almeida DP (2010) Modelagem matemática para descrição da cinética de secagem do Feijão Adzuki (vigna angularis). Revista Brasileira de Produtos Agroindustriais 12(2):171-178.
Rodovalho RS, Silva HW, Silva IL, Rosseto CAV (2015) Cinética de secagem dos grãos de pimenta bode. Global Science and Technology 8(2):128-142.

Silva HW, Rodovalho RS, Velasco MF, Silva CF, Vale LSR (2016) Kinetics and thermodynamic properties related to the drying of "Cabacinha" pepper fruits. Revista Brasileira de Engenharia Agrícola e Ambiental 20(2):174-180.

Silva LMM, Souza FC, Souza LP, Moreira MER, Mata C, Duarte MEM (2014). Modelos de predição da cinética de secagem dos grãos de guandu. Brazilian Journal Food Technology 17(4):310-318.

Siqueira VC, Resende O, Chaves TH (2012) Cinética de secagem dos grãos de pinhão manso. Revista Ceres 59(2):171-177.

Smaniotto TAS, Resende O, Sousa KA, Oliveira DEC, Campos RC (2017) Drying kinetics of sunflower grains. Revista Brasileira de Engenharia Agrícola e Ambiental 21(3):203-208.

Sousa KA, Resende O, Chaves TH, Costa LM (2011) Cinética de secagem do nabo forrageiro (Raphanussativus L.). Revista Ciência Agronômica 42(4):883-892.

Verma LR, Bucklin RA, Endan JB, Wratter FT (1985) Effects of drying air parameters on rice drying models. Transactions of the ASAE 28(1):296-301.

Wang CY, Singh RP (1978) Use of variable equilibrium moisture content in modeling rice drying. Transaction of ASAE 11(78):668-672.

Yagcioglu A, Degirmencioglu A, Cagatay F (1999) Drying characteristics of laurel leaves under different conditions. In: BAS CETINCELIK A, (ed.) Proceedings of the seventh international congress on agricultural mechanization and energy, 26-27 May, Adana, Turkey. 